\title{
Epigenetics could explain some Moroccan population colorectal cancers peculiarities: microsatellite instability pathway exploration
}

Mohammed Sekal ${ }^{* *}$, Hassania Ameurtesse ${ }^{1}$, Laila Chbani ${ }^{1}$, Karim Ouldim², Sanae Bennis², Mohammed Abkari ${ }^{3}$, Amal Boulouz ${ }^{2}$, Dafr Allah Benajah ${ }^{3}$, Basher Benjelloun ${ }^{4}$, Abdelmalek Ousadden ${ }^{4}$, Khalid Ait Taleb ${ }^{4}$, Said Ait Laalim , Imane Toghrai ${ }^{4}$, Khalid Mazaz ${ }^{4}$, Samia Arifi ${ }^{5}$, Nawfel Mellas ${ }^{5}$, Karima El Rhazi ${ }^{6}$, Taoufiq Harmouch',

Sidi Adil Ibrahimi ${ }^{3}$ and Afaf Amarti Riffi ${ }^{1}$

\begin{abstract}
Background: Colorectal Cancers (CRC) are one of the most common malignancies in the world. Their incidence in Morocco, between 2005 and 2007, was 5.6 for 100000 inhabitants, which is very low compared to what found in developed countries. In addition, CRCs show a high frequency of rectal localizations, and occurs in a younger population in Morocco compared to what found in developed countries.

The purpose of this study is to confirm these CRC peculiarities in Morocco and try to explain them by exploring the microsatellite instability molecular pathway.

Methods: This is a prospective observational study conducted since January 2010, including 385 patients admitted in Hassan II University Hospital of Fez. We collected clinical, radiological and pathological data. We investigated the expression of mismatch repair (MMR) proteins in 214 patients and BRAF gene mutations in 159 patients.
\end{abstract}

Results: Mean age was $55.08+/-15.16$ years. $36.5 \%$ of patients were less than 50 years old and $49.3 \%$ of tumors were localized in the rectum. Loss of MMR protein expression was observed in $11.2 \%$ of cases. It was independently associated with individual or family history of cancer belonging to Hereditary Non-Polyposis Colorectal Cancer (HNPCC) spectrum $(p=0.01)$ and proximal localization $(p=0.02)$. No BRAF mutation was detected in all cases.

Conclusions: These results confirm the high occurrence of CRCs to young patients and the high frequency of rectal localizations in Moroccan population. They mostly show an absence of BRAF mutation, supposing a rarity of MLH1 promoter hypermethylation pathway, which may even partially explain the CRC peculiarities in our context.

Virtual Slides: The virtual slide(s) for this article can be found here: http://www.diagnosticpathology.diagnomx.eu/vs/ 5868184711716884

Keywords: Colorectal cancer, Microsatellite instability, BRAF gene, DNA methylation

\section{Background}

Colorectal cancers (CRC) are one of the most common malignancies representing the third most common cancer for men and the second for women in the world [1]. Their incidence in Morocco, between 2005 and 2007, was 5.6 for 100000 inhabitants [2]. Several previous epidemiological studies demonstrated that the CRC

\footnotetext{
* Correspondence: doc.med@hotmail.com

'Department of pathology, University hospital Hassan II of Fez, Fez, Morocco Full list of author information is available at the end of the article
}

incidence in Morocco is similar to that in neighboring Maghreb countries but very low compared to what found in developed countries [3] (Table 1). In addition, CRCs show a high frequency of rectal localizations and occur more to a younger population compared to what found in developed countries [2, 4]. According to the Casablanca Moroccan Region Cancer Registry, the rectal cancer mean age occurrence is 58.1 years for men and 54.2 years for women; and the colon cancer mean age occurrence is 56.8 years for men and 57.2 years for women [2]. 
Table 1 Comparison of estimated CRC incidence rate (for 100,000 inhabitants) in Morocco with that in other countries in 2012 [3]

\begin{tabular}{llllll}
\hline & Morocco & Tunisia & USA & Canada & France \\
\hline Men & $9-16.1$ & $9-16.1$ & $16.1-32.2$ & $>32.2$ & $>32.2$ \\
Women & $<4.5$ & $4.5-7.6$ & $>21.8$ & $>21.8$ & $>21.8$ \\
\hline
\end{tabular}

CRC develop through a multistep carcinogenic process with an accumulation of epigenetic and genetic changes. So for the same histology, the underlying molecular abnormalities can be very different and could explain the wide variation in clinical course and responses to therapies for different patients. Several molecular mechanisms are implicated in CRC carcinogenesis: Chromosomal Instability (CIN), MicroSatellite Instability (MSI) and the CpG Island Methylator Phenotype (CIMP) [5].

CIN pathway is found in about $85 \%$ of sporadic CRC and in familial adenomatous polyposis. It is characterized by loss or gain of chromosome arms, chromosomal translocations or gene amplifications [6]. This 'traditional pathway' is the most well characterized which involves the progression of a conventional type adenoma that may acquire mutation or loss of $A P C$, mutation of $K R A S$ and TP53, and chromosomal instability before the occurrence of an invasive adenocarcinoma [7].

MSI pathway is found in approximately $15 \%$ of sporadic CRC and $95 \%$ of Hereditary Non-Polyposis Colorectal Cancer (HNPCC) syndrome $[8,9]$. Microsatellites are short repetitive DNA sequences found throughout the tumor genome that are prone to mutations [10]. MSI occurs in the case of DNA mismatch repair $(M M R)$ genes inactivation $(\mathrm{MLH1}, \mathrm{MSH} 2, \mathrm{MSH} 6$ or PMS2) secondary to germline or somatic mutations. MMR deficiency leads to DNA replication errors within microsatellites [11].

Two sub-types of CRC MSI-high have been described:

- One resulting from Germline $M M R$ mutations associated to HNPCC Syndrome, an autosomal dominant disorder that accounts for $\sim 3 \%$ of all CRC [12].

- The other from a somatic epigenetic event in the promoter of a single DNA mismatch repair gene $(M L H 1)$ [12]. The later subset is known as sporadic MSI-H colorectal cancer and is also characterized by extensive methylation of multiple gene promoter regions called the $\mathrm{CpG}$ island methylator phenotype (CIMP). Approximately $20 \%$ of CRCs are CIMP-high tumors and are thought to arise from serrated polyps [13]. Sporadic MSI-H colorectal cancers frequently exhibit hotspot mutations in the BRAF oncogene [14]. $B R A F$ encodes a serine/threonine kinase that is an essential component of the RAF/MEK/ERK/MAPK signaling cascade which promotes cellular proliferation and anti-apoptotic effects. In CRC, BRAF mutations are located in a hotspot in exon 15 that leads to a V600E single-amino-acid substitution [15]. BRAF mutation is considered a marker for the serrated pathway and is found in approximately $10-15 \%$ of $\mathrm{CRC}$, including the majority of those showing CIMP [16]. It is associated with $M L H 1$ promoter methylation, indicates a sporadic MSI CRC and essentially excludes a diagnosis of HNPCC (Lynch) syndrome [15, 17, 18].

The aim of this study is to confirm the CRC peculiarities in Moroccan population. Then, to explore the micro satellite instability molecular pathway with the hypotheses, which it could explain these CRC peculiarities, particularly the differences in incidence between Morocco and developed countries.

\section{Methods}

This is a prospective observational study conducted since January 2010, including 385 patients with CRC, admitted in Hassan II University Hospital of Fez.

\section{Ethics statements}

Written, informed consent was obtained from each patient involved in this observational study. This research was approved by Hassan II University Hospital Ethics Committee.

\section{Study Population and Histological Features}

We collected clinical and endoscopic data (age, sex, personal and family history and tumor localization), radiological data (extension to adjacent organs, visceral metastasis), and pathological data (Histologic type and differentiation, local invasion, lymph node metastasis, peritoneal carcinomatosis...). Classification of CRC was done according to 2010 World Health Organization criteria for histological type, differentiation and tumor stage.

\section{Expression of DNA Mismatch Repair Proteins}

Immunohistochemical analysis of DNA mismatch repair proteins MLH1 and MSH2 was performed on Ventana Benchmark Ultra automaton in 214 tumor samples. To increase the sensitivity of immunohistochemistry, we also studied the expression of MSH6 and PMS2 by the same technique $[12,19]$.

Four $\mu \mathrm{m}$ tissue sections from formalin-fixed paraffinembedded tissue were stained with antibodies against hMLH1 (clone G168-728; Cell marque), hMSH2 (clone G219-1129; Cell Marque), hMSH6 (clone BC/44; Cell Marque), and PMS2 (clone MRQ-28; Cell Marque). Absence of nuclear staining in tumor cells with the presence of positive staining in surrounding cells 
(lymphocytes or normal glandular cells) was interpreted as a loss of expression of these proteins.

\section{DNA isolation}

One representative tissue section and the corresponding paraffin block were selected. The tumor area was marked on the Hematoxylin eosin-stained slide. The percentage of tumor cells in the marked area and the relative amounts of different histoanatomical components of the tumor were estimated to guarantee a valid tumor cell content. DNA was then extracted from formalin-fixed, paraffin-embedded tissue with the QIAamp DNA mini kit (Qiagen ${ }^{\circ}$, Hilden, Germany) following the manufacturer's instructions. Moreover, the isolated DNA quality and amplified products were determined by optical density $\left(\mathrm{OD}_{260 / 280}\right)$ measurements $\left(\right.$ Nanoview $\left.^{\circ}\right)$.

\section{Microsatellite Instability Assay}

Microsatellite instability (MSI) was assessed in 7 tumor samples with loss of expression of MMR proteins by the Molecular Pathology laboratory in Bergonie Institute, Bordeaux (France), using a fluorescent multiplex PCRbased method with a set of five mononucleotide markers (BAT25, BAT26, NR21, NR22, NR24). Polymerase chain reaction (PCR) for the various microsatellite markers was carried out only on tumor DNA. Standard PCR conditions were used. Primers were custom ordered with various fluorescent dyes from life technologies. The analysis of variability in the length of PCR product corresponding to the microsatellite markers was performed on ABI 3100 (life technologies ${ }^{\odot}$ ). Tumors were classified as MSI-high if $>2$ of the 5 markers are unstable; microsatellite stable (MSS) when there is an absence of instability and MSI-low if only 1 marker is unstable. This latter is considered as a MSS status.

\section{Detection of BRAF Mutations \\ Mutant allele-specific PCR}

Tumor DNA was analyzed in $159 \mathrm{CRC}$ to detect the V600E point mutation in exon 15 of the BRAF gene by the use of an allele-specific PCR using mutation-specific primers. This PCR was performed in a final volume of $50 \mu \mathrm{l}$ containing $2 \mu \mathrm{l}$ of forward primer: 5'-GGTG ATTTTGGTCTAGCTACATA-3', tow $\mu$ l of reverse primer 5'-GGCCAAAAATTTAATCAGTGGA-3' (12.5 $\mu \mathrm{Ml}), 0.4 \mu \mathrm{l}$ of Taq polymerase Platinium ${ }^{\circ}, 5 \mu \mathrm{l}$ of Mix 10X Buffer (Invitrogen $\left.{ }^{\circ}\right), 1 \mu \mathrm{l}$ of dNTPs $(10 \mathrm{mM}), 2 \mu \mathrm{l}$ of $\mathrm{MgCl}_{2}(50 \mathrm{mM}), 32.6 \mu \mathrm{l}$ of free DNA/RNA water and $50 \mathrm{ng}$ of DNA. Then, an agarose gel electrophoresis was performed for the resulting PCR products with a positive control containing the BRAF V600E mutation.

\section{PCR- direct sequencing}

In addition, for all tumors with loss of expression of MMR proteins, and 6 tumors with conservation of expression of MMR proteins, the result of the $B R A F$ allelespecific PCR was confirmed by screening of $B R A F$ (exon 15) using direct sequencing of PCR products in forward and reverse. PCR products generated using the following primer pairs: forward 5'-TGCTTGCTCTGATAGGA AAATG-3' and reverse 5'-GTAACTCAGCAGCATCTC AGGG-3'. This PCR was performed in a final volume of $50 \mu \mathrm{l}$, containing $0.4 \mu \mathrm{l}$ of Taq polymerase Platinium ${ }^{\circ}$, $5 \mu \mathrm{l}$ of Mix 10X Buffer (Invitrogen $\left.{ }^{\circ}\right), 1 \mu \mathrm{l}$ of dNTPs $(10 \mathrm{mM}), 2 \mu \mathrm{l}$ of forward and reverse primers $(12.5 \mu \mathrm{M})$, $2 \mu \mathrm{l}$ of $\mathrm{MgCl}_{2}(50 \mathrm{mM}), 32.6 \mu \mathrm{l}$ of free DNA/RNA water, and $50 \mathrm{ng}$ of DNA. Thermocycling was performed at $95{ }^{\circ} \mathrm{C}$ for $10 \mathrm{~min}$, followed by 35 cycles of $95{ }^{\circ} \mathrm{C}$ for $30 \mathrm{~s}, 60{ }^{\circ} \mathrm{C}$ for $60 \mathrm{~s}$ and $72{ }^{\circ} \mathrm{C}$ for $30 \mathrm{~s}$, and one last cycle of $72{ }^{\circ} \mathrm{C}$ for $10 \mathrm{~min}$. The resulting PCR products were purified, and tested for the presence of mutations by bi-directional Sanger sequencing on the 3500 Genetic Analyzer (Applied Biosystems ${ }^{\circ}$ ) using the original PCR primers and the BigDye ${ }^{\circ}$ Terminator V1.1 Cycle Sequencing Kit (Life technologies, Foster City, CA, USA), according to the manufacturer's recommendations.

These tests are ongoing for the remaining patients.

\section{Statistics analysis}

The data were analyzed on the software EPI Info version 3.4 .

- Firstly, we studied all independent variables distribution of: age, sex, personal or family history of cancer belonging to HNPCC spectrum, histological and immunohistochemical parameters.

- In second time, we compared patients with preserved MMR proteins and patients with loss of MMR protein expression using the chi-square test and Fisher's exact test. Values were considered statistically significant when $\mathrm{p}<0.05$.

\section{Results}

\section{Descriptive study}

\section{Clinical and radiological features}

Mean age was $55.08+/-15.16$ years. $36.5 \%$ of patients were less than 50 years old. Sex ratio M/F $=1.05$.

$10.1 \%$ of patients had an individual or family history of cancer belonging to HNPCC spectrum. At diagnosis, the average tumor size was $5.8+/-$ $2.5 \mathrm{~cm} .49 .3 \%$ of tumors were located in the rectum, while the proximal locations accounted for only $19.4 \%$.

$26.3 \%$ of patients presented with one or several visceral metastasis. Secondary localizations were mainly liver, lung and ovary (Fig. 1). 


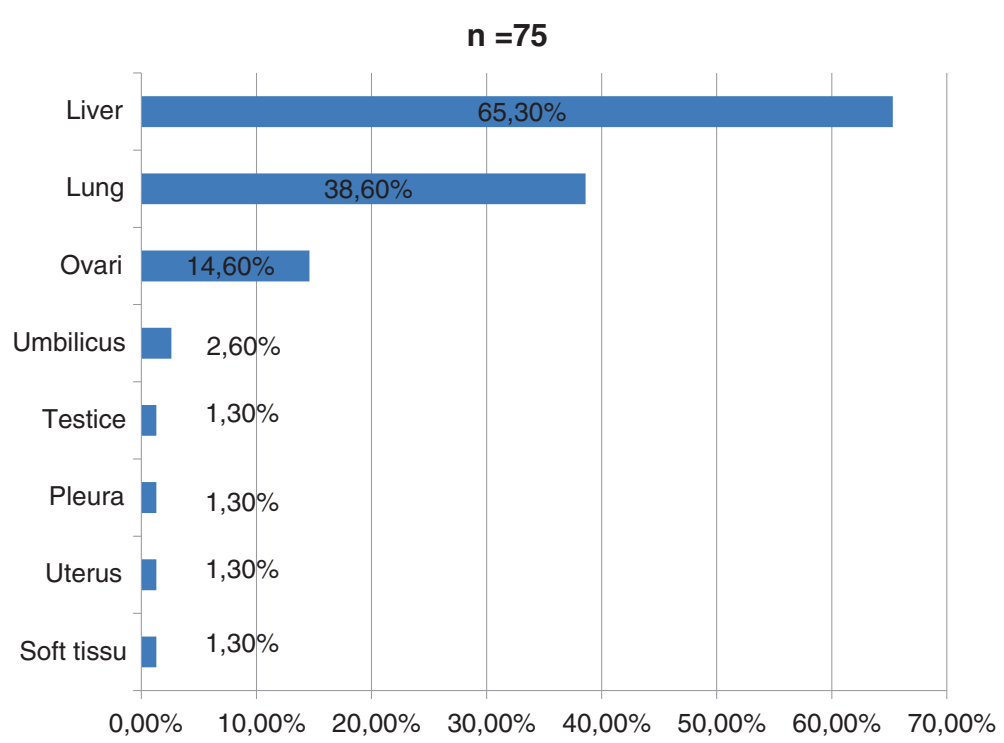

Fig. 1 Distribution of metastatic sites at diagnosis

\section{Pathological features}

Adenocarcinoma was the most common histological type found in $88.1 \%$ of cases. $92.5 \%$ of tumors are well or moderately differentiated. Mucinous component and Independent cells component are found in $16.1 \%$ and $6 \%$ of tumors respectively.

pT3 Stage was the most common found in $78.4 \%$ of cases. Synchronous CRC were present in $3.9 \%$ of cases. Extension to adjacent organs, lymph metastasis and peritoneal carcinomatosis were found respectively at $13.9 \%$, $29.6 \%$ and $15.6 \%$ of patients (Details in Table 2).

Loss of MMR protein expression was observed in $11.2 \%$ of cases. It is dominated by the simultaneous loss of MLH1 and PMS2 proteins which represents 2/3 of cases with MMR protein loss (Figs. 2 and 3). Table 3 shows the principal clinical and pathological features of patients with loss of expression of MMR proteins.

\section{Molecular analysis}

Microsatellite instability was confirmed in 7 tumor samples using microsatellite instability assay (Fig. 4).

V600E BRAF mutation detection was performed on 159 cases, and did not find any mutation (Figs. 5 and 6). This test is in progress for the remaining cases.

Data have been deposited in Cosmic database. Accession Numbers: (unique id_study, 605).

\section{Analytical study}

Univariate analysis demonstrated significant association between loss of MMR proteins with the presence of Individual or family history of cancer belonging to HNPCC spectrum $(\mathrm{p}=0.001)$, Lymph node metastasis $(\mathrm{p}=0.02)$, synchronous colorectal cancer $(\mathrm{p}=0.0003)$ and proximal localization $(\mathrm{p}=0.00001)$. Associations with histologic type, tumor stroma and the presence of visceral metastasis were not statistically significant.

However, in multivariate analysis, only individual or family history of cancer belonging to HNPCC spectrum $(\mathrm{p}=0.01$, Odds ratio $=35.8$ [95\% CI 2.2- 588]); and proximal location $(\mathrm{p}=0.02$, Odds ratio $=21[95 \% \mathrm{CI}$ 1.4-316.3]) were confirmed to be associated with loss of expression of MMR proteins (Details in Table 4).

\section{Discussion}

The frequency of $M L H 1$ promoter methylation in sporadic CRC varied from $0.0 \%$ [20] to $66.9 \%$ [21]. In one Meta-analysis including 5584 patients, the frequency of MLH1 promoter methylation in unselected CRC was $20.3 \%$ [22]. These cancers with MLH1 methylation are more commonly observed within older females. It may be due to estrogen decrease with age and could explain why the MSI-H status is more common for women [23].

In our study, we didn't find any case of CRC with both MMR proteins expression loss and BRAF mutation. This result confirms an earlier study led in Hassan II University Hospital of Fez, which took 62 samples of patients with sporadic colorectal adenocarcinomas brought in our pathology laboratory before 2010 . So, only one patient (1.6\%) carried BRAF codon 600 mutation [24], that is lower than what found in literature, were $B R A F$ mutations are found out in approximately $10-15 \%$ of CRC. In Tunisia, where population is similar to Morocco, one study, including 51 patients with $\mathrm{CRC}$, found out also just one patient with a $B R A F$ somatic mutation and this tumor has a MSS status [25]. Further analysis of $M L H 1$ promoter methylation status in the tumor of 4 patients 
Table 2 Clinicopathological and Immunohistochemical Characteristics in CRCs. Fez, Morocco, 2010-2013

\begin{tabular}{|c|c|c|}
\hline Characteristics & & $\begin{array}{l}\text { Frequencies } \\
(\%)\end{array}$ \\
\hline \multirow[t]{2}{*}{ Gender $(n=385)$} & Male & 51.4 \\
\hline & Female & 48.6 \\
\hline \multirow[t]{2}{*}{ Age rang $(n=385)$} & $<50$ years & 36.5 \\
\hline & $>50$ years & 63.5 \\
\hline \multirow{2}{*}{$\begin{array}{l}\text { Individual or family history of } \\
\text { cancer belonging to HNPCC } \\
\text { spectrum ( } n=208)\end{array}$} & Yes & 10.1 \\
\hline & No & 89.9 \\
\hline \multirow[t]{8}{*}{ Localization ( $n=385$ ) } & Ascending colon & 14.4 \\
\hline & Transverse colon & 4.8 \\
\hline & Descending colon & 4.8 \\
\hline & Sigmoid & 17.9 \\
\hline & $\begin{array}{l}\text { Recto-sigmoid } \\
\text { junction }\end{array}$ & 9.1 \\
\hline & Upper rectum & 6.7 \\
\hline & Through rectum & 20.6 \\
\hline & Lower rectum & 21.7 \\
\hline \multirow[t]{3}{*}{ Histologic type $(n=385)$} & Adenocarcinoma & 88.1 \\
\hline & $\begin{array}{l}\text { Mucinous } \\
\text { carcinoma }\end{array}$ & 8.6 \\
\hline & $\begin{array}{l}\text { Independent cells } \\
\text { carcinoma }\end{array}$ & 3.4 \\
\hline \multirow{4}{*}{$\begin{array}{l}\text { Histological differentiation } \\
(n=385)\end{array}$} & Well & 66 \\
\hline & Average & 26.5 \\
\hline & Poor & 6.8 \\
\hline & Undifferentiated & 0.8 \\
\hline \multirow{2}{*}{$\begin{array}{l}\text { Mucinous component } \\
(n=385)\end{array}$} & Yes & 16.1 \\
\hline & No & 83.9 \\
\hline \multirow{2}{*}{$\begin{array}{l}\text { Independent cells component } \\
(n=385)\end{array}$} & Yes & 6 \\
\hline & No & 94 \\
\hline \multirow{2}{*}{$\begin{array}{l}\text { Vascular embolus }(n=270) \\
\text { ((surgical specimens only) }\end{array}$} & Yes & 16.1 \\
\hline & No & 83.9 \\
\hline \multirow{2}{*}{$\begin{array}{l}\text { Perineural invasion }(n=270 \text { ) } \\
\text { (surgical specimens only) }\end{array}$} & Yes & 9.9 \\
\hline & No & 90.1 \\
\hline \multirow{4}{*}{$\begin{array}{l}\text { Synchronous colorectal lesion } \\
(n=359)\end{array}$} & Cancer & 3.9 \\
\hline & Single adenoma & 11.4 \\
\hline & $\begin{array}{l}\text { Multiple } \\
\text { adenomas }\end{array}$ & 3.1 \\
\hline & No & 81.6 \\
\hline \multirow{4}{*}{$\begin{array}{l}\text { Stage pT }(n=222) \text { (only surgical } \\
\text { specimens without } \\
\text { radiochemotherapy) }\end{array}$} & 1 & 0.5 \\
\hline & 2 & 12.6 \\
\hline & 3 & 78.4 \\
\hline & $4 b$ & 8.6 \\
\hline \multirow{3}{*}{$\begin{array}{l}\text { Lymph node metastasis }(n=270 \text { ) } \\
\text { (surgical specimens only) }\end{array}$} & Yes & 29.6 \\
\hline & No & 60.4 \\
\hline & 0 & 60.4 \\
\hline
\end{tabular}

Table 2 Clinicopathological and Immunohistochemical Characteristics in CRCs. Fez, Morocco, 2010-2013 (Continued)

\begin{tabular}{|c|c|c|}
\hline \multirow{5}{*}{$\begin{array}{l}\text { Stage } p N(n=270) \text { (surgical } \\
\text { specimens only) }\end{array}$} & $1 \mathrm{mic}$ & 0.4 \\
\hline & $1 a$ & 12.6 \\
\hline & $1 b$ & 10.7 \\
\hline & $2 \mathrm{a}$ & 8.9 \\
\hline & $2 b$ & 7 \\
\hline \multirow{2}{*}{$\begin{array}{l}\text { Radiological or/and pathological } \\
\text { aspect of extension to adjacent } \\
\text { organs ( } n=303 \text { ) }\end{array}$} & Yes & 13.9 \\
\hline & No & 86.1 \\
\hline \multirow[t]{2}{*}{ Visceral metastasis $(n=285)$} & Yes & 26.3 \\
\hline & No & 73.7 \\
\hline \multirow[t]{2}{*}{ Peritoneal carcinomatosis $(n=288)$} & Yes & 15.6 \\
\hline & No & 84.4 \\
\hline \multirow[t]{3}{*}{ Stage $M(n=285)$} & 0 & 65.6 \\
\hline & $1 \mathrm{a}$ & 14.4 \\
\hline & $1 b$ & 20 \\
\hline \multirow{2}{*}{$\begin{array}{l}\text { Expression of MMR proteins }(I H C) \\
(n=214)\end{array}$} & Loss & 11.2 \\
\hline & Conservation & 88.8 \\
\hline \multirow{2}{*}{$\begin{array}{l}\text { MMR proteins not expressed } \\
(n=24)\end{array}$} & MLH1 and PMS2 & 66.7 \\
\hline & MSH2 and MSH6 & 33.3 \\
\hline
\end{tabular}

showing MSI-H phenotype and MLH1 protein expression loss with absence of $M L H 1$ deleterious somatic mutation by Multiplex Ligation-dependent Probe Amplification (MLPA) or sequencing, did not detect aberrant methylation discarding the hypothesis of sporadic cancers due to epigenetic inactivation of MLH1 gene [25]. Another element that reinforces our results is the rarity of serrated lesions in our context. In an earlier study conducted in our laboratory between 2004 and 2007, we did not find any serrated adenoma among 86 colorectal polyps [26]. On the other hand, the MMR protein

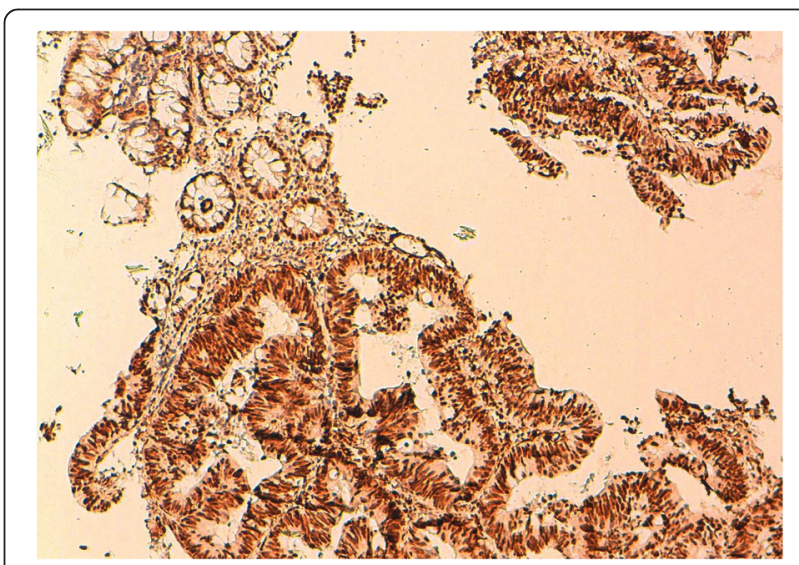

Fig. 2 Immunohistochemical study of a colonic adenocarcinoma using anti-MSH2 antibodies (Grossissment x200): Conservation of MSH2 expression both in normal mucosa and carcinoma cells 


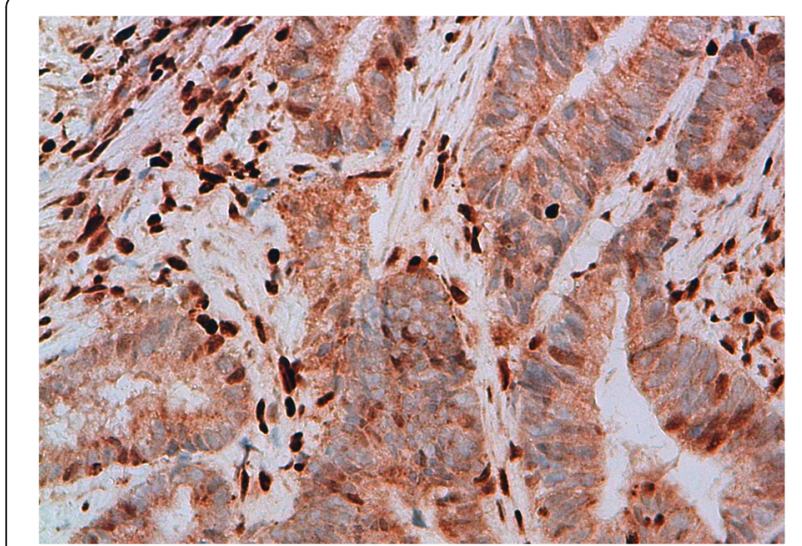

Fig. 3 Immunohistochemical study of a colonic adenocarcinoma using anti-MLH1 antibodies (Grossissment x400): Loss of MLH1 expression in tumor cells (Internal control positive) expression loss was independently associated in this study with personal or family history of cancer belonging to HNPCC spectrum. This is another index for the high rate of HNPCC syndrome. One study on MLH1 and MLH2 germline mutations is in progress in our laboratory.

MSI-H phenotype is associated with proximal tumor location, poor differentiation and/or mucinous histology, dense lymphocyte infiltration and low frequency of lymph node and distant organ metastasis [10]. In our study, CRCs with MMR protein loss were associated with proximal tumor location. We also found that $49.3 \%$ of CRC are located in the rectum. This confirms data of The Casablanca Moroccan Region Cancer Registry which show that $43.2 \%$ of CRC are located in the rectum [2]. This is a further demonstration of the relative increase in rectal locations for Moroccan population which is very high compared to what is observed in Europe, where it varies between 20 and $35 \%$ [27].

In contrast to colon cancer, rectal cancer missed V600E BRAF mutations [28]. Gaedcke and al detected no V600E BRAF mutations in 94 rectal cancer patients

Table 3 Principal clinical and pathological features of patients with MMR proteins loss. Fez, Morocco, 2010-2013

\begin{tabular}{|c|c|c|c|c|c|c|c|c|c|}
\hline Cases & Age & Gender & Localization & Histologic type & Histologic Differenciation & Stage $\mathrm{pT}$ & Stage $\mathrm{pN}$ & Stage M & $\overline{\text { Lost proteins }}$ \\
\hline 1 & 45 & Male & Right colon & Adenocarcinoma & well & 2 & 0 & 0 & $\overline{M L H 1 / P M S 2}$ \\
\hline 2 & 45 & Male & Right colon & Mucinous Carcinoma & well & 3 & 0 & 0 & MSH2/MSH6 \\
\hline 3 & 49 & Male & Rectum & Adenocarcinoma & well & $x$ & $x$ & $1 a$ & MLH1/PMS2 \\
\hline 4 & 80 & Female & Right colon & Adenocarcinoma & average & 3 & 0 & $1 a$ & MLH1/PMS2 \\
\hline 5 & 54 & Male & Left colon & Mucinous Carcinoma & average & 3 & 0 & $x$ & MSH2/MSH6 \\
\hline 6 & 64 & Female & Right colon & Adenocarcinoma & well & 3 & 0 & 0 & MLH1/PMS2 \\
\hline 7 & 38 & Male & Right colon & Adenocarcinoma & well & 3 & 0 & $x$ & MLH1/PMS2 \\
\hline 8 & 61 & Male & Right colon & Adenocarcinoma & well & 3 & $1 \mathrm{a}$ & $x$ & MLH1/PMS2 \\
\hline 9 & 41 & Male & Left colon & Adenocarcinoma & well & $x$ & $x$ & $1 b$ & MSH2/MSH6 \\
\hline 10 & 55 & Male & Right colon & Adenocarcinoma & poor & 3 & 0 & $x$ & MSH2/MSH6 \\
\hline 11 & 48 & Male & Right colon & Adenocarcinoma & poor & $4 a$ & 0 & $1 b$ & MSH2/MSH6 \\
\hline 12 & 31 & Male & Rectum & Adenocarcinoma & average & $x$ & $x$ & $1 \mathrm{a}$ & MLH1/PMS2 \\
\hline 13 & 71 & Male & Left colon & Adenocarcinoma & average & 3 & $2 a$ & $1 a$ & MLH1/PMS2 \\
\hline 14 & 70 & Male & Rectum & Adenocarcinoma & well & 3 & $2 a$ & $x$ & MLH1/PMS2 \\
\hline 15 & 81 & Male & Right colon & Adenocarcinoma & poor & 3 & 0 & $x$ & MLH1/PMS2 \\
\hline 16 & 50 & Female & Left colon & Adenocarcinoma & average & $x$ & $x$ & $1 a$ & MLH1/PMS2 \\
\hline 17 & 56 & Female & Right colon & Adenocarcinoma & average & $4 b$ & 0 & $1 b$ & MLH1/PMS2 \\
\hline 18 & 50 & Female & Right colon & Adenocarcinoma & average & 3 & 0 & $1 b$ & MLH1/PMS2 \\
\hline 19 & 28 & Male & Right colon & Adenocarcinoma & poor & 3 & 0 & 0 & MLH1/PMS2 \\
\hline 20 & 53 & Male & Right colon & Adenocarcinoma & well & 3 & 0 & 0 & MSH2/MSH6 \\
\hline 21 & 74 & Male & Left colon & Adenocarcinoma & average & 3 & 0 & 0 & MLH1/PMS2 \\
\hline 22 & 53 & Male & Right colon & Adenocarcinoma & well & 3 & 0 & 0 & MSH2/MSH6 \\
\hline 23 & 70 & Male & Not specified & Adenocarcinoma & well & $x$ & $x$ & $x$ & MSH2/MSH6 \\
\hline 24 & 56 & Male & Left colon & Adenocarcinoma & well & $4 b$ & 0 & 0 & MLH1/PMS2 \\
\hline
\end{tabular}



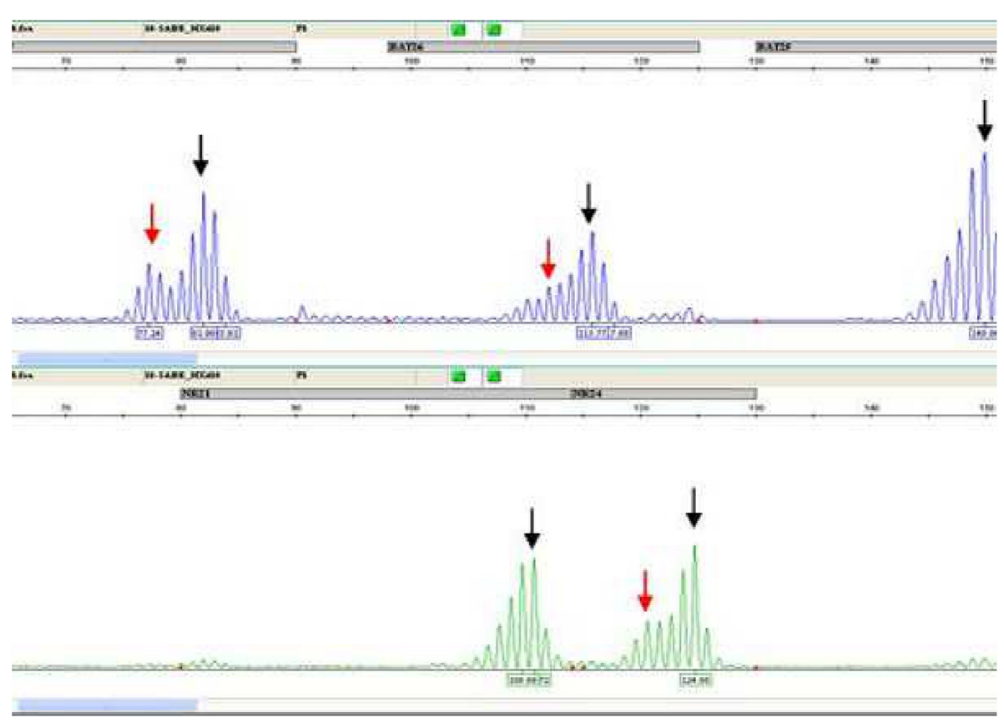

Fig. 4 DNA fragment length analysis showing a profile MSI-H: supernumerary peak at 3/5 markers

suggesting that $B R A F$ mutations [28] and consequently MLH1 gene promoter hypermethylation $[15,17,18]$ do not seem to play any role in rectal cancer pathogenesis. The rarity of $M L H 1$ gene promoter hypermethylation pathway in Moroccan context could explain the relative high frequency of rectal locations which is in fact caused by a reduction in the number of patients with right location. This would also contribute partially to an overall decrease in the number of CRCs in our context and therefore explain the relative low incidence of CRC.

MLH1 Promoter hypermethylation is not an isolated process, but part of an overall epigenetic DNA methylation process. For example, in other studies, sporadic MSI tumors were associated with higher rates of hypermethylation of the PTEN tumor suppressor gene compared to MSS tumors [29]. To explain the probable rarity of $M L H 1$ promoter hyper methylation in our regional context, we suggest several hypotheses:

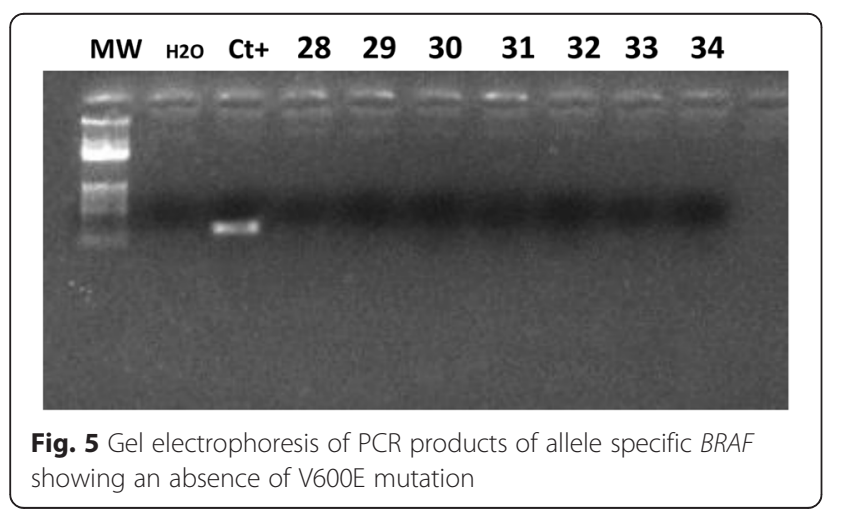

1- Some reports noticed that DNA methylation process may be influenced by genetic factors. Genetic variants polymorphisms at a specific locus can influence both regional and distant DNA methylation [30]. Twin and family-based studies suggest that a significant proportion of inter-individual variability in DNA methylation is determined genetically [31]. Relatives of CRC cases with $M L H 1$ methylation present increased risk of colorectal, stomach and ovarian cancer, suggesting that there may be a heritable factor for $\mathrm{CRC}$ and other cancers associated with MLH1 methylation in non-HNPCC Syndrome CRC [32]. The rarity of hypermethylation in Tunisian patients with CRC [25] could be related to genetic variants. This could also be present within Moroccan population who's ethnically similar and geographically close to the Tunisian population; and explain the observed absence of BRAF somatic mutations.

2- Age is an important risk factor in the development of colorectal cancers [33]. The cause of age-related aberrant methylation is not known. It is possible that upregulation of the de novo methyltransferase DNMT3b could be responsible for the hypermethylation seen in aging [34]. Approximately half of genes which can be involved in age-related methylation are also involved in the pathogenesis of colon cancer, suggesting a role for these genes in the increased cancer susceptibility associated to age [35]. Moroccan population is relatively young compared to developed countries. For example, in 2010, the elderly of more than 60 years was $8.4 \%$ in Morocco [36], against $20.9 \%$ in France [37]. In addition, in 2011, life expectancy at birth in Morocco was 72 years, against 82 years 


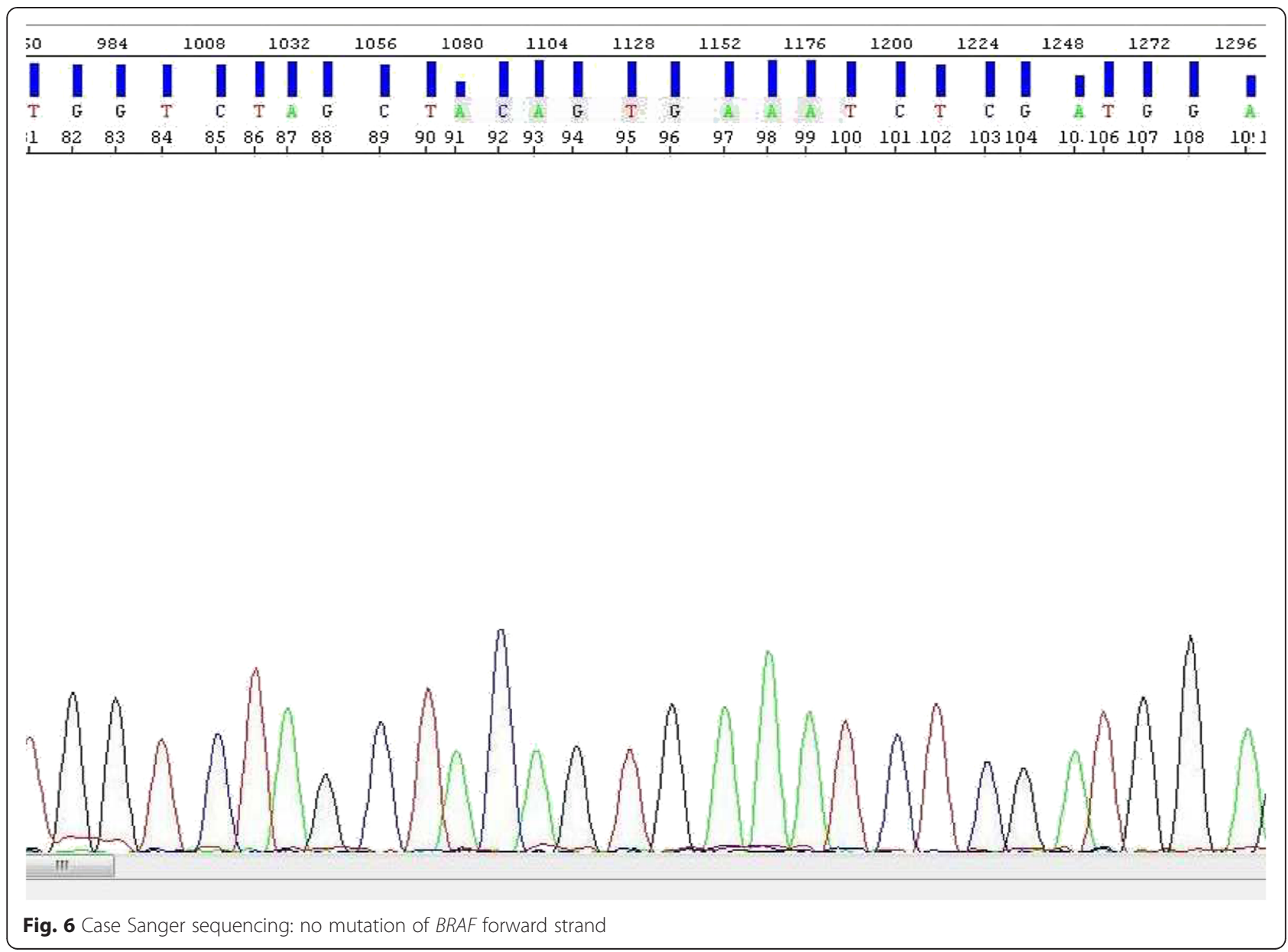

in France and Canada [38]. The relatively low life expectancy in our context may explain the rarity of age related $M L H 1$ promoter hyper methylation pathway. Youth of our population could also explain the high proportion of young patients, less than 50 years, which is $36.5 \%$ against $6 \%$ in Europe [27].

3- Epigenetic drift might be due to the accumulation of small errors in copying DNA methylation marks during successive cell divisions [39]. It has been observed that older monozygotic twin pairs demonstrate greater DNA methylation differences than younger monozygotic twin pairs [40]. The differences between twins were greater for pairs that spent less of their lifetime together or exhibited more different lifestyles suggesting that environmental factors play a role in epigenetic drift [40]. Some carcinogens and environmental factors have been implicated:

a- Cigarette smoke is considered one of the most powerful environmental modifiers of DNA methylation [41]. In a prospective study $(\mathrm{n}=37399)$, cigarette smoking was associated with $B R A F$ mutation-positive CRC subtype with a positive dose-response relationship indicating epigenetic modification, which may be functionally involved in smoking-related colorectal carcinogenesis [42]. Carcinogens in cigarette smoke, such as arsenic, chromium, formaldehyde, polycyclic aromatic hydrocarbons, and nitrosamines, can damage DNA by causing double-stranded breaks. Survivor cells display a high capacity for DNA repair. But, the DNA repair sites recruit DNMT1, which methylates CpGs adjacent to the repaired nucleotides [43, 44]. Smoking prevalence is relatively lower in Morocco compared to developed countries. For example, in 2009, the prevalence of smoking among patients over 15 years in Morocco was $33 \%$ for men and $2 \%$ for women, while this prevalence was $36 \%$ for men and $27 \%$ for women in France [38]. This could also explain the rarity of MLH1 promoter hyper methylation pathway in our context.

b- Alcohol is considered one of the factors associated with DNA methylation. Alcohol may induce aberrant DNA methylation patterns alterations; these generally are associated with modulation of the pathways that regulate the availability of S-adenosylmethionine [45]. 
Table 4 Clinicopathological characteristics in CRCs with MMR proteins expression loss/conservation. Fez, Morocco, 2010-2013

\begin{tabular}{|c|c|c|c|c|c|}
\hline \multirow[t]{2}{*}{ Characteristics } & \multirow{2}{*}{$\begin{array}{l}\text { Loss of } \\
\text { expression } \\
\text { of MMR } \\
\text { proteins }\end{array}$} & \multirow{2}{*}{$\begin{array}{l}\text { Conservation } \\
\text { of expression } \\
\text { of } \\
\text { MMR } \\
\text { proteins }\end{array}$} & \multirow{2}{*}{$\begin{array}{l}\text { Univariate } \\
\text { analysis } \\
\text { (p) }\end{array}$} & \multicolumn{2}{|c|}{ Multivariate analysis } \\
\hline & & & & $\bar{p}$ & Odds ratio \\
\hline Means Age (years) & 55.1 & 56.4 & 0.7 & & \\
\hline Age rang $<50$ years & $8 / 24$ & $60 / 190$ & 0.48 & & \\
\hline $\begin{array}{l}\text { Presence of individual or family history of cancer } \\
\text { belonging to HNPCC spectrum }\end{array}$ & $4 / 9$ & $9 / 190$ & 0.001 & 0.01 & $35.8[95 \%$ Cl 2.2- 588] \\
\hline Well or moderately differentiated adenocarcinoma & $15 / 24$ & $145 / 190$ & 0.07 & & \\
\hline Presence of independent cells component & $2 / 24$ & $13 / 190$ & 0.52 & & \\
\hline Presence of mucinous component & $5 / 24$ & $33 / 190$ & 0.43 & & \\
\hline Presence of perineural invasion & $1 / 19$ & $12 / 139$ & 0.51 & & \\
\hline Presence of vascular embolus & $4 / 19$ & $21 / 139$ & 0.35 & & \\
\hline Presence of lymph node metastasis & $3 / 19$ & $53 / 138$ & 0.02 & & \\
\hline Presence of synchronous colorectal cancer & $6 / 23$ & $5 / 185$ & 0.0003 & & \\
\hline $\begin{array}{l}\text { Presence of radiological or/and pathological } \\
\text { extension to adjacent organs }\end{array}$ & $4 / 21$ & $16 / 147$ & 0.22 & & \\
\hline Presence of visceral metastasis & $6 / 17$ & $31 / 132$ & 0.21 & & \\
\hline Presence of peritoneal carcinomatosis & $4 / 20$ & $21 / 146$ & 0.35 & & \\
\hline Location & - & - & 0.00001 & 0.02 & $21[95 \%$ Cl 1.4-316.3] \\
\hline Right colon & $14 / 23$ & $31 / 184$ & - & - & \\
\hline Left colon & $6 / 23$ & $64 / 184$ & - & - & \\
\hline Rectum & $3 / 23$ & $89 / 184$ & - & - & \\
\hline
\end{tabular}

Indeed, in chronic alcoholics, serum folate levels are significantly reduced compared with healthy subjects. Folic acid deficiency reduces the enzyme S-adenosylmethionine levels [46]. In addition, people with low folate intake/high alcohol intake show a higher frequency of promoter methylation of genes involved in CRC carcinogenesis (e.g., APC-1A, p14ARF, p16INK4a, hMLH1, O6-MGMT, and $R A S S F 1 A$ ) compared with people with high folate intake/low alcohol intake [47]. One meta-analysis including 27 cohort and 34 case-control studies showed a $21 \%$ increased risk of CRC, for moderate drinkers and $52 \%$ increased risk of CRC for heavy drinkers (4 drinks/day) with a dose-risk relationship [48]. Alcoholism prevalence is very lower in Morocco compared to developed countries. For example, in 2008 , the prevalence of alcoholism in patients over 15 years was $1.2 \%$ in Morocco, against $12.5 \%$ in France [38]. This could also explain the rarity of MLH1 promoter hyper methylation pathway in our context.

c- Diet has been described as an important factor in colorectal carcinogenesis. Several studies have shown that the highest adherence to Mediterranean diet resulted in a significantly risk reduction for CRC $[49,50]$. In a Moroccan cross-sectional survey, $70.1 \%$ of the sample $(\mathrm{n}=2214)$ has a highest adherence to Mediterranean diet [51]. However, a study of this diet impact on CRC associated with MLH1 promoter hypermethylation should be considered to confirm this hypothesis.

Advances in our understanding of colorectal cancer molecular pathology has led to the identification of promising early detection molecular markers for use in non-invasive colorectal cancer screening assays. At this time, stool-based methylated VIMENTIN (mVim) is a clinically validated marker for early colorectal cancers detection which is now available in the United States under the name ColoGuard assay (LabCorp ${ }^{\circ}$ [52]. In addition, in Europe, there is a blood-based assay that detects methylated SEPT9 which is being marketed as a colon cancer screening assay under the name Epi proColon (Epigenomics $\mathrm{AG}^{\oplus}$ ) [52]. However, the rarity of CIMP-high CRC could make these screening methods, inadequate in our context.

\section{Conclusions}

In Morocco, the rarity of $B R A F$ mutation was confirmed in our study that found no cases of CRC with this mutation. MMR proteins expression loss was statistically associated with the presence of Individual or family 
history of cancer belonging to HNPCC spectrum. These two elements suppose a rarity of MLH1 promoter hypermethylation, likely involved in carcinogenesis of CRC. Further studies are needed to confirm this data which partly explain some peculiarities of this pathology in Morocco, such as the relative high frequency of rectal localizations and low incidence. The relative youth of Moroccan population could also explain the high rate of young patients with CRC.

This rarity of MLH1 promoter hypermethylation pathway in Moroccan population could be explained by the relative low life expectancy or/and the relative low prevalence of smoking and alcoholism or/and the highest adherence to Mediterranean diet.

Lastly, in Morocco and other third world countries, given the adoption in the future of a modern lifestyle and the increase of life expectancy who participate in DNA hypermethylation damage, we consequently expect the continuation of the upward trend in the incidence of this scourge.

\begin{abstract}
Abbreviations
CRC: Colorectal cancer; DNA: Deoxyribonucleic acid; RNA: Ribonucleic acid; CIN: Chromosomal Instability; MSI: Microsatellite instability; MMR: Mismatch repair; CIMP: CpG Island Methylator Phenotype; HNPCC: Hereditary Non-Polyposis Colorectal Cancer; PCR: Polymerase chain reaction; CGIs: CpG islands; MSS: Microsatellite stable; MLPA: Multiplex Ligation-dependent Probe Amplification; DNMTs: DNA methyltransferases
\end{abstract}

\section{Competing interests}

The authors declare that they have no competing interests.

\section{Authors' contributions}

SM has made substantial contributions to conception and design acquisition, analysis and interpretation of data. He has been involved in drafting the manuscript. $\mathrm{HA}$ and $\mathrm{AB}$ have made substantial contributions to acquisition of data. They have been involved in revising manuscript critically for important intellectual content. SB has made substantial contributions to analysis and interpretation of molecular data. She has been involved in revising the manuscript critically for important intellectual content; KER has made substantial contributions to conception and design, analysis and interpretation of data. She has been involved in revising the manuscript critically for important intellectual content. LC, KO, MA, DAB, BB, AO, KAT, IT, SAA, KM, SA, NM, TH, SAI and AAR have made substantial contributions to conception and design. They have been involved in revising the manuscript critically for important intellectual content. All authors read and approved the final manuscript.

\section{Acknowledgments}

We thank the team of pathology and molecular pathology department of Bergonié Institute (Bordeaux, France) who conducted the analysis of microsatellite instability.

\footnotetext{
Author details

'Department of pathology, University hospital Hassan II of Fez, Fez, Morocco. ${ }^{2}$ Department of molecular genetics, University hospital Hassan II of Fez, Fez, Morocco. ${ }^{3}$ Department of gastroenterology, University hospital Hassan II of Fez, Fez, Morocco. ${ }^{4}$ Department of visceral surgery, University hospital Hassan II of Fez, Fez, Morocco. ${ }^{5}$ Department of oncology, University hospital Hassan II of Fez, Fez, Morocco. ${ }^{6}$ Department of epidemiology, University hospital Hassan II of Fez, Fez, Morocco.
}

Received: 11 May 2015 Accepted: 12 June 2015

Published online: 24 June 2015

\section{References}

1. GLOBOCAN 2008 website. Cancer Fact Sheet. International Agency for Research on Cancer: World Health Organization. Available: http://www.iarc.fr/ en/publications/pdfs-online/wcr/2008/index.php. Accessed 19 June 2010.

2. Benider A, Harif M, karkouri M, Quessar A, Sahraoui S, Sqalli S. Registre des cancers du grand Casablanca, année 2005-2007. Association lalla Salma de lutte contre le cancer.(Edition 2012). http://www.contrelecancer.ma/ site_media/uploaded_files/RCRC_-_28_mai_2012.pdf. P:43-50. Accessed 16 june 2015.

3. World health organization. International Agency for Research on Cancer (IARC). GLOBOCAN 2012: Estimated cancer Incidence, Mortality and Prevalence Worldwide. http://www.iarc.fr/en/publications/pdfs-online/wcr/ 2008/index.php. Accessed 16 june 2015.

4. Laila C, Imane H, Mohamed B, Chakib N, Afaf A. Digestive cancers in Morocco: Fez-Boulemane region. Pan Afr Med J. 2012;13:46.

5. Roock WD, Vriendt VD, Normanno N, Ciardiello F, Tejpar SKRAS, BRAF. PIK3CA, and PTEN mutations: implications for targeted therapies in metastatic colorectal cancer. Lancet Oncol. 2011;12:594-603.

6. Grady WM, Carethers JM. Genomic and epigenetic instability in colorectal cancer pathogenesis. Gastroenterology. 2008;135:1079-99.

7. Fearon ER, Vogelstein B. A genetic model for colorectal tumorigenesis. Cell. 1990;61:759-67.

8. Poynter JN, Siegmund KD, Weisenberger DJ, Long TI, Thibodeau SN, Lindor N et al. Molecular characterization of MSI-H colorectal cancer by MLHI promoter methylation, immunohistochemistry, and mismatch repair germline mutation screening. Cancer Epidemiol Biomarkers Prev. 2008;17:3208-15.

9. Tannergard P, Liu T, Weger A, Nordenskjold M, Lindblom A. Tumorigenesis in colorectal tumors from patients with hereditary non-polyposis colorectal cancer. Hum Genet. 1997;101:51-5.

10. Kloor M, Staffa L, Ahadova A, von Knebel Doeberitz M. Clinical significance of microsatellite instability in colorectal cancer. Langenbecks Arch Surg. 2014;399(1):23-31.

11. Peltomäki P. Deficient DNA, mismatch repair: a common etiologic factor for colon cancer. Hum Mol Genet. 2001;10:735-40.

12. Hampel H, Frankel WL, Martin E, et al. Screening for the Lynch syndrome (hereditary nonpolyposis colorectal cancer). N Engl J Med. 2005;352(18):1851-60.

13. Morimoto LM, Newcomb PA, Ulrich CM, et al. Risk factors for hyperplastic and adenomatous polyps: evidence for malignant potential? Cancer Epidemiol Biomarkers Prev. 2002;11(10Pt1):1012-8.

14. Weisenberger DJ, Siegmund KD, Campan M, et al. CpG island methylator phenotype underlies sporadic microsatellite instability and is tightly associated with BRAF mutation in colorectal cancer. Nat Genet. 2006:38:787-93.

15. Davies H, Bignell GR, Cox C, Stephens P, Edkins S, Clegg S, et al. Mutations of the BRAF gene in human cancer. Nature. 2002;417:949-54.

16. Rajagopalan H, Bardelli A, Lengauer C, Kinzler KW, Vogelstein B, et al. Tumorigenesis: RAF/RAS oncogenes and mismatch-repair status. Nature. 2002:418(6901):934.

17. Bettstetter M, Dechant S, Ruemmele P, Grabowski M, Keller G, et al. Distinction of hereditary non polyposis colorectal cancer and sporadic microsatellite-unstable colorectal cancer through quantification of MLH1 methylation by real-time PCR. Clin Cancer Res. 2007;13:3221-8.

18. Domingo E, Niessen RC, Oliveira C, Alhopuro P, Moutinho C, Espin E, et al. BRAF-V600E is not involved in the colorectal tumorigenesis of HNPCC in patients with functional MLH1 and MSH2 genes. Oncogene. 2005;24:3995-8.

19. Truninger $\mathrm{K}$, Menigatti M, Luz J, et al. Immunohistochemical analysis reveals high frequency of PMS2 defects in colorectal cancer. Gastroenterology. 2005;128(5):1160-71.

20. Belshaw NJ, Elliott GO, Williams EA, Bradburn DM, Mills SJ, et al. Use of DNA from human stools to detect aberrant $\mathrm{CpG}$ island methylation of genes implicated in colorectal cancer. Cancer Epidemiol Biomarkers Prev. 2004;13(9):1495-501.

21. Kumar K, Brim H, Giardiello F, Smoot DT, Nouraie M, et al. Distinct BRAF (V600E) and KRAS mutations in high microsatellite instability sporadic colorectal cancer in African Americans. Clin Cancer Res. 2009;15(4):1155-61.

22. Li $X$, Yao $X$, Wang $Y$, Hu F, Wang $F$, Jiang $L$, et al. MLH1 promoter methylation frequency in colorectal cancer patients and related clinicopathological and molecular features. PLoS One. 2013;8(3):e59064. doi:10.1371/journal.pone.0059064. 
23. Koo JH, Leong RW. Sex differences in epidemiological, clinical and pathological characteristics of colorectal cancer. J Gastroenterol Hepatol. 2010;25:33-42.

24. Bennani B, Gilles S, Fina F, Nanni I, Ibrahimi A, Amarti Riffi A, et al. Mutation analysis of BRAF exon 15 and KRAS codons 12 and 13 in Moroccan patients with colorectal cancer. Int J Biol Markers. 2010;25(4):179-84.

25. Aissi S, Buisine MP, AI PN. Somatic molecular changes and histo-pathological features of colorectal cancer in Tunisia. World J Gastroenterol. 2013;19(32):5286-94.

26. Draoui I. Histopathological aspects of gastrointestinal polyps, about 120 cases. PhD in Medicine, Faculty of Medicine and Pharmacy of Fez. 2009. Available: http://scolarite.fmp-usmba.ac.ma/cdim/mediatheque/theses/ theses09.php. Accessed: 01 March 2014.

27. Remontet L, Estève J, Bouvier AM, Grosclaude P, Launoy G, Menegoz F, et al. Cancer incidence and mortality in France over the period 1978-2000. Public Rev Epidemiol Sante. 2003;51(1Pt1):3-30.

28. Gaedcke J, Grade M, AI JK. KRAS and BRAF mutations in patients with rectal cancer treated with preoperative chemoradiotherapy. Radiother Oncol. 2010:94:76-81.

29. Goel A, Arnold CN, Niedzwiecki D, Carethers JM, Dowell JM, AI WL. Frequent inactivation of PTEN by promoter hypermethylation in microsatellite instability-high sporadic colorectal cancers. Cancer Res. 2004;64:3014-21.

30. Hitchins MP, Wong JJ, Suthers G, et al. Inheritance of a cancer-associated MLH1 germ-line epimutation. N Engl J Med. 2007;356:697-705.

31. Kaminsky ZA, Tang T, Wang SC, Ptak C, Oh GH, Wong AH A. DNA methylation profiles in monozygotic and dizygotic twins. Nat Genet. 2009:41:240-5

32. Levine AJ, Win AK, Buchanan DD, Jenkins MA, Baron JA, Young JP, et al. Cancer risks for the relatives of colorectal cancer cases with a methylated MLH1 promoter region: data from the Colorectal Cancer Family Registry. Cancer Prev Res (Phila). 2012;5(2):328-35.

33. Ahuja N, Issa JP. Aging, methylation and cancer. Histol Histopathol. 2000;15:835-42.

34. Casillas Jr MA, Lopatina N, Andrews LG, Tollefsbol TO. Transcriptional control of the DNA methyltransferases is altered in aging and neoplastically-transformed human fibroblasts. Mol Cell Biochem. 2003;252:33-43.

35. Wilson $\mathrm{VL}$, Jones PA. DNA methylation decreases in aging but not in immortal cells. Science. 1983:220:1055-7.

36. Moroccans' High Commission for Planning. Social Indicators Morocco 2010. p:14.

37. The French National Institute for Statistics and Economic Studies. Available: http://www.insee.fr/. Accessed 22 January 2014.

38. World Health Organization. World Health Statistics 2013. Available:http:// www.who.int/gho/publications/world_health_statistics/2013/en/ Accessed 2 January 2015.

39. Martin GM. Epigenetic drift in aging identical twins. Proc Natl Acad Sci U S A. $2005 ; 102: 10413-4$

40. Fraga MF, Ballestar E, Paz MF, Ropero S, Setien F, Ballestar ML A. Epigenetic differences arise during the lifetime of monozygotic twins. Proc Natl Acad Sci U S A. 2005;102:10604-9.

41. Breitling LP, Yang R, Korn B, Burwinkel B, Brenner H. Tobacco-smoking-related differential DNA methylation: $27 \mathrm{~K}$ discovery and replication. Am J Hum Genet. 2011;88:450-7.

42. Limsui D, Vierkant RA, Tillmans LS, et al. Cigarette smoking and colorectal cancer risk by molecularly defined subtypes. J Natl Cancer Inst. 2010;102:1012-22

43. Mortusewicz O, Schermelleh L, Walter J, Cardoso MC, Leonhardt H. Recruitment of DNA methyltransferase I to DNA repair sites. Proc Natl Acad Sci U S A. 2005;102:8905-9.

44. Cuozzo C, Porcellini A, Angrisano T, Morano A, Lee B, Al DPA. DNA damage, homology-directed repair, and DNA methylation. PLoS Genet. 2007;3:e110. doi:10.1371/journal.pgen.0030110.

45. Kim YI. Nutritional epigenetics: Impact of folate deficiency on DNA methylation and colon cancer susceptibility. J Nutr. 2005;135(11):2703-9.

46. Cravo ML, Glória LM, Selhub J, et al. Hyperhomocysteinemia in chronic alcoholism: Correlation with folate, vitamin B-12, and vitamin B-6 status. Am J Clin Nutr. 1996;63(2):220-4.

47. Van Engeland M, Weijenberg MP, Roemen GM, et al. Effects of dietary folate and alcohol intake on promoter methylation in sporadic colorectal cancer: The Netherlands cohort study on diet and cancer. Cancer Res. 2003;63(12):3133-7.
48. Fedirko V, Tramacere I, Bagnardi V, Rota M, Scotti L, Islami F, et al. Alcohol drinking and colorectal cancer risk: an overall and dose-response meta-analysis of published studies. Ann Oncol. 2011;22:1958-72.

49. Bamia C, Lagiou P, Buckland G, Al TA. Mediterranean diet and colorectal cancer risk: results from a European cohort. Eur J Epidemiol. 2013;28(4):317-28.

50. Schwingshackl L, Hoffmann G. Adherence to Mediterranean diet and risk of cancer: A systematic review and meta-analysis of observational studies. Int J Cancer. 2014;135(8):1884-97.

51. El Rhazi K, Nejjari C, Romaguera D, Feart C, Obtel M, Zidouh A, et al. Adherence to a Mediterranean diet in Morocco and its correlates: cross-sectional analysis of a sample of the adult Moroccan population. BMC Public Health. 2012;12:345. doi:10.1186/1471-2458-12-345.

52. Itzkowitz SH et al. Improved fecal DNA test for colorectal cancer screening. Clin Gastroenterol Hepatol. 2007;5:111-7.

\section{Submit your next manuscript to BioMed Central and take full advantage of:}

- Convenient online submission

- Thorough peer review

- No space constraints or color figure charges

- Immediate publication on acceptance

- Inclusion in PubMed, CAS, Scopus and Google Scholar

- Research which is freely available for redistribution 